\title{
Pioneers in Dermatology and Venereology: an interview with Prof. Lawrence C. Parish.
}

Lawrence Charles Parish

Thomas Jefferson University

Follow this and additional works at: https://jdc.jefferson.edu/dcbfp

Part of the Dermatology Commons

Let us know how access to this document benefits you

\section{Recommended Citation}

Parish, Lawrence Charles, "Pioneers in Dermatology and Venereology: an interview with Prof. Lawrence C. Parish." (2019). Department of Dermatology and Cutaneous Biology Faculty

Papers. Paper 115.

https://jdc.jefferson.edu/dcbfp/115

This Article is brought to you for free and open access by the Jefferson Digital Commons. The Jefferson Digital Commons is a service of Thomas Jefferson University's Center for Teaching and Learning (CTL). The Commons is a showcase for Jefferson books and journals, peer-reviewed scholarly publications, unique historical collections from the University archives, and teaching tools. The Jefferson Digital Commons allows researchers and interested readers anywhere in the world to learn about and keep up to date with Jefferson scholarship. This article has been accepted for inclusion in Department of Dermatology and Cutaneous Biology Faculty Papers by an authorized administrator of the Jefferson Digital Commons. For more information, please contact: JeffersonDigitalCommons@jefferson.edu. 


\section{Please send us a General CV (with year of birth).}

See attached. October 12, 1938, Cambridge, Massachusetts

\section{What brought you to Dermatology?}

As a fourth-year medical student, I took a month's rotation at the University of Pennsylvania. Dermatology came alive under the leadership of Donald M. Pillsbury, Walter B. Shelley, and Albert M. Kligman. Their mulitiauthored textbook, Dermatology, had brought dermatology into the modern era.

When Dermatology, by Pillsbury, Shelley, and Kligman made its debut in 1956, it was widely heralded as the first new dermatology text to appear in many years. A handsome one-volume work of 1282 pages, it was unique because it emphasized diagnosis through the study of primary and secondary lesions, distribution patterns, associated systemic findings, "applied" physiology, and psychologic aspects. It carefully avoided using terms that the authors considered complex and outmoded as designations for dermatologic disease.

I attended Tufts University School of Medicine in Boston, where dermatology was not held with the esteem that it was or is in Philadelphia. I was hooked and have been in Philadelphia ever since, save for two years in the Army.

\section{Who were your most important teachers?}

- Benjamin Spector - Professor of Bioanatomy and the History of Medicine at Tufts. - A patient is not just a case but a real person

- Walter B. Shelley - Professor of Dermatology at Penn - Imaginative therapy

- Donald M. Pillsbury - Professor of Dermatology at Penn - How to deal with and treat patients

- Herman Beerman - Professor of Dermatology at Penn - The role of dermatopathology in confirming a clinical impression 
4. From whom did you learn most?

- Herbert A. Luscombe - Professor of Dermatology at Jefferson-A true gentleman who demonstrated how to overcome adversity to lead a productive life (He had disabling multiple sclerosis from his late twenties).

- John H. Talbott - Editor-in-Chief, Journal of the American Medical Association - The influence of a medical journal and how to present both new and old material in a palatable fashion

- Ferdinand Biguria - Chief of the $3^{\text {rd }}$ Medical Service (Tufts), Boston City Hospital - The excitement of making a good diagnosis

- Louis Weinstein - Professor of Medicine (Infectious Diseases) at Tufts - The significance of infection in disease causation and the proper role of antimicrobial agents.

5. Please list your 5 best publications!

1. An historical approach to the nomenclature of rheumatoid arthritis. PARISH LC. Arthritis Rheum. 1963 Apr:6:138-58. No abstract available. PMID:

13941445.

2. Histopathology of the decubitus ulcer. Witkowski JA, Parish LC.

J Am Acad Dermatol. 1982 Jun;6(6):1014-21.

PMID:

7096663

3. Wax models in dermatology.

Parish LC, Worden G, Witkowski JA, Scholz A, Parish DH. Trans Stud Coll Physicians Phila. 1991 Mar;13(1):29-74. No abstract available. 
PMID:

2038761

4. The assessment of acne: an evaluation of grading and lesion counting in the measurement of acne.

Witkowski JA, Parish LC.

Clin Dermatol. 2004 Sep-Oct:22(5):394-7. Review.

PMID:

15556725

5. The importance of the history of dermatology: An American viewpoint.

Parish LC.

Clin Dermatol. 2019 Jan - Feb:37(1):60-70. doi:

10.1016/j.clindermatol.2018.09.012. Epub 2018 Sep 17.

PMID:

30554625

6. Have you ever been president or in the leadership of an academic society?

- Historian of the American Academy of Dermatology, 1970 - 1980

- Founder and President of the History of Dermatology Society, 1973 -

- Founder and Chairman of the Section on Dermatology of the College of Physicians of Philadelphia, 1983 - 1986

- Founder of the Council of Dermatology Editors, 1985 -

- Founder and President of the International Academy of Cosmetic Dermatology, 1995 -

7. What was your greatest achievement in your professional life?

Fostering the development of the history of dermatology as an important discipline

8. What was your greatest disappointment in your life? 
Having acne as a teen-ager that left me with many ice-pick scars. I was made to think that it was my fault. If only I followed a proper diet and applied the available concoctions, the pimples would disappear. My father was an allergist and took me to see several prominent dermatologists. Following their advice, which ranged from not eating cooked sugar to growing out of it and from staph toxoid injections to superficial $x$-ray, still did not stop the ravages. I was even religious in applying Acnome|® to no available. Most embarrassing was a store owner who suggested I keep my hands out of my trouser pockets.

9. What was your most funny experience in your professional life? Joe Witkowski and I used to write papers on Tuesday evenings. We alternated between Joe's house in Mayfair and mine in Society Hill, 7 miles apart. One Tuesday, we got our signals mixed. Joe went to my house, and I went to his.

10. Whom would you list among the top ten dermatologists (please name only deceased persons)

- J. Martin Beare

- Herman Beerman

- John Thorne Crissey

- Stefania Jablonska

- Emiliano Panconesi

- Donald M. Pillsbury

- Arthur J. Rook

- Walter B. Shelley

- Günter Stüttgen

- Marion B. Sulzberger 
- Joseph A. Witkowski

- Tae Ha Woo

11. Whom would you list among the top ten of living dermatologists?

- Robert Baran

- Martin Black

- Jean Bolognia

- Irwin Braverman

- Lowell Goldsmith

- Jane Grant-Kels

- Warren Heymann

- Mark Lebowhl

- Samuel Moschella

12. What will be the greatest problem for Dermatology in the next ten years?

Government intervention. Every government interferes with the practice of medicine by causing increased problems and wasted time. For example, the electronic medical record (EMR), while good in concept, creates innumerable problems, ranging from decreased interaction between physician and patient to the recording and regurgitation of redundant and often unnecessary information in order to placate the insurance company and/or the government.

At one time, it was the malpractice crisis. In some states, this tragic intervention has subsided, but the mere thought of malpractice suits occupies mental time that could be better spent on patient care.

13. What will be the next breakthrough in the coming ten years in Dermatology? 
The scourge of acne may actually be eliminated. A half century ago, psoriasis in its severe forms could even be fatal. Instead of tar baths and total body applications of various steroids and other agents, there are now biologics. Decades ago, atopic dermatitis, once it had been identified by Sulzberger and Wise, was treated by emollients, wet wraps, and even parentectomies (sending the child to Arizona to be away from the parents and the accompanying anxiety). Epidermolysis bullosa and even the various types of ichthyosis may be tamed or relegated to historical texts (i.e. chloasma) through gene therapy. While acne congloblata does not have to create life ruining scars as in the case of Marian Sulzberger's sister, acne is still a significant problem. Despite the wonders of the retinoids, one that can still be life damaging, 